\title{
NUMERICAL AND DIGITAL METHODS IN ANALYSIS OF SPACE-TIME CHANGES AND RENEWAL OF VEGETATION COVER RESOURCES IN THE CZARNA RIVER VALLEY
}

\author{
Grażyna Łaska' \\ 1 Department of Environmental Protection and Management, Bialystok University of Technology, Wiejska 45a, \\ 15-351 Białystok, Poland; e-mail: g.laska@pb.edu.pl
}

Received: 2015.06.06 Accepted: 2015.08.31 Published: 2015.10.01

\begin{abstract}
The study aimed at evaluation of the current state and description of changes in plant communities in wetland habitats in the Czarna river valley and at recommendation of effective methods for the renewal of vegetation on the basis of detail analysis of its spacetime changes. The methods applied included a compilation of field studies (inventory, cartographic study and phytosociological analyses), valorisation of nature, numerical syntaxonomy with the use of MVSP program (Cluster Analysis and PCA) and digital methods GIS (Geomedia Professional 6.1). The field study of the vegetation cover of the Czarna river valley was performed in the years 2010-2011. The space-time analysis of changes in the vegetation cover and renewal of vegetation was made with the use of archive aerial photographs from 1966, topographic maps from 1982 and 2000 and orthophotomaps from 2011. The vegetation cover of the Czarna river valley was found to be composed of 12 plant communities representing 6 syntaxonomic classes, and to include sites of 8 protected species. The space-time analysis of the vegetation cover of the Czarna river valley, taking into account the changes in the forms of the valley use over the period 1966-2011, showed that the area occupied by forest communities in wetland habitats as a result of secondary succession has increased by $0.16 \mathrm{~km}^{2}$, so by $27 \%$ with respect to the area of $0.4406 \mathrm{~km}^{2}$ from 1966. Chronological changes in the vegetation cover over this area analysed on the basis of GIS and digital methods indicate that in the wet meadows in the valley studied the secondary succession leads to the reproduction of the potential forest communities that were growing there once in the past. The renewal of forestless greeneries in the Czarna river valley is related to changes in the use of the area realised by mowing and restoration of the earlier hydrological regime in the entire catchment area, changed by the network of channels and drainage ditches.
\end{abstract}

Keywords: numerical syntaxonomy, digital technique GIS, vegetation communities maps, valorisation indices, secondary succession, vegetation cover.

\section{INTRODUCTION}

Human activity and changes in the way of using the areas of river valleys analysed in the spacetime scale have revealed their significant effect on the vegetation cover [Kryszak et al. 2004, Gamrat \& Burczyk 2007, Kryszak \& Kryszak 2007, Grzelak et al. 2008, Kamiński 2008]. The status and direction of changes in the plant communities of river valleys are the outcome of changes in the water conditions and hydrologic regime in the entire catchment area, shaped by anthropogenic activity [Dembek et al. 2002, Kryszak \& Grynia 2005, Gamrat et al. 2010].

In the second half of the $20^{\text {th }}$ century, the catchment area of the Czarna River was deforested and assigned for agricultural use as grassland. The valley was cut by a network of drainage ditches, which decreased the water level in the river and reduced the surface flooding leading to overdrying of hydrogenic habitats. In the 1980's, large areas of agricultural land were abandoned or crossed out from the agricultural use land register, which resulted in abandonment of mowing 
and using the land as pasture. The land that was still mown, used as pasture and fertilised developed stable meadow communities.

In the 1990s, further abandonment of agricultural use of the valley led to further changes in the water conditions of the habitats and in meadow communities. The above described changes are typical anthropogenic ones [Kozłowska 2002, Piórkowski 2002, Matysiak \& Dembek 2006, Łaska 2008, 2009, 2012]. In the Czarna river valley about $0.3 \%$ of the meadow communities is currently used as mown meadows, while the rest of the land has been abandoned. The aim of the study was to evaluate the current status of plant communities in the wetland habitats in the Czarna river valley and to suggest directions of their further changes on the basis of detail space-time analysis. The problem is important as the Czarna river valley is in the area protected under Natura 2000 (Knyszyńska Refuge), introduced to maintain the spontaneous ecological processes, stability of biotopes and preservation of their biological diversity [Kotowski 2002]. The valorisation of the Czarna river valley nature is the basis for determination of the range of its protection and defining the rules of rational use of the available resources in consistence with the predispositions of meadow ecosystems for certain functions in the landscape [Myśliwy 2010, Łaska 2011].

\section{MATERIAL AND METHODS}

The study was performed in the NE Poland, Knyszyńska Forest, near the village of Ruda Rzec$\mathrm{zka}$, in the upper section of the Czarna river, at about $1 \mathrm{~km}$ from its spring. The evaluation of the current status and directions of changes in plant communities in the area studied was performed on the basis of the analysis of 4 sheets of topographic maps, including 2 sheets in the scale 1:25000 "Supraśl" (245.22) and "Sochonie" (245.21) and 2 sheets in the scale 1:10000 "Ożynnik" (245.221) and "Wólka Ratowiecka" (245.212), a topographic map in the scale 1:5000 from the Geoportal [www. geoportal.gov.pl]. The analysis of space-time structure of the landscape of the_Czarna river valley, taking into account the changes in the forms of land use, was based on the aerial photographs from 1966 in the scale 1:18000 and from 1982 in the scale 1:25000 [CODGiK, Warszawa], orthophotomap sheets from 2006 in the scale 1:10000 [MŚ, Warszawa] and topographic maps in the scale $1: 10000$, in the coordinate system " 65 " from 1982 and in the system "92" from 2000 [OPGK, Białystok]. The materials were used for reconstruction of the changes in the vegetation cover in the Czarna river valley in the years 1966-2011.

The field study in the Czarna river valley was carried out from September 2010 to the middle of July 2011, in three periods: after completion of field work in mown meadows and arable land (02.09.2010), in the period of early spring appearance of geophytes (30.04-13.05.2011) and in full vegetation season (08-10.07.2011). The field study included the phytosociological analyses of plant communities, cartographic study of vegetation and sites of protected plant species with the use of GPS technique and identification of habitats of the plant patches studied. In forest communities in the area of $400 \mathrm{~m}^{2}(20 \times 20 \mathrm{~m})$ and in the forestless area of $100 \mathrm{~m}^{2}(10 \times 10 \mathrm{~m}) 72$ phytosociological Braun-Blanquet releves were taken. The assignment of species to particular syntaxonomic units was assumed after Matuszkiewicz [2001], vascular plants nomenclature was assumed after Mirek et al. [2002], and nomenclature of bryophytes - after Ochyra et al. [2003].

Plant communities were identified on the basis of the method of numerical syntaxonomy [MVSP ver. 3.2], taking into account the hierarchic cluster classification (Cluster Analysis) and methods of indirect ordination PCA (Principal Components Analysis). The classification algorithms used employed the agglomeration methods based on analysis of the matrix of similarity coefficients. The floristic similarity between the releves was expressed in the percentage scale (Percent Similarity). The clustering was based on the unweighted pair group method with arithmetic mean (UPGMA), the hierarchic classification of communities was presented in a form of a dendrogram. In the principal components analysis, based on the covariance matrix, the variable parameters were the data on species composition of particular plant communities whose centring was made (Centre data), in which each species is weighted according to its variance. The valorisation of the vegetation cover in the Czarna river valley was made assuming the rules developed for valorisation of the nature of wetlands and hydrogenic habitats by Oświt [2000].

Changes in the vegetation cover in the Czarna river valley over the years 1966-2011 were analysed on the basis of the program GIS (Geomedia Professional ver. 6.1), employing the method of cho- 
ropleth map of basic area of $400 \mathrm{~m}^{2}(20 \times 20 \mathrm{~m})$. The map of plant communities and sites of protected plant species in the Czarna river valley near the village Ruda Rzeczka, was made in the scale of $1: 800$ on the basis of the fundamental map in the scale 1:5000 [PODGiK, Białystok].

\section{RESULTS}

In the floristic diversity of the Czarna river valley near the village of Ruda Rzeczka 12 plant communities were identified representing six phytosociological classes (Figure 1). Syntaxonomy of the particular plant syntaxons is according with Matuszkiewicz [2001] as it follows:

Class (Cl.) Molinio-Arrhenatheretea R. Tx. 1937 Order (O.) Molinietalia caeruleae W. Koch 1926

Alliance (All.) Filipendulion ulmariae Segal 1966

Association (Ass.) Lysimachio vulgaris-Filipenduletum Bal.-Tul. 1978

All. Calthion palustris R. Tx. 1936 em. Oberd. 1957

Community with Deschampsia caespitosa

Ass. Scirpetum silvatici Ralski 1931

Ass. Angelico-Cirsietum oleracei R. Tx. 1937 em, Oberd. 1967

Cl. Phragmitetea R.Tx. et Prsg 1942

O. Phragmitetalia W. Koch 1926

All. Phragmition W. Koch 1926

Ass. Phragmitetum australis (Gams 1927) Schmale 1939

All. Magnocaricion W. Koch 1926

Ass. Caricetum acutiformis Sauer 1937

Ass. Caricetum appropinquatae (Koch 1926) Soó 1938

Cl. Alnetea glutinosae Br.-Bl. et R.Tx.1943

O. Alnetalia glutinosae R. Tx.1937

All. Alnion glutinosae (Malc. 1929) Meijer Drees 1936

Ass. Salicetum pentandro-cinereae (Almq. 1929) Pass. 1961

Cl. Querco-Fagetea Br.-Bl. et Vlieg. 1937

O. Fagetalia sylvaticae Pawł. in Pawł., Sokoł. et Wall. 1928

All. Alno-Ulmion Br.-B1. et R.Tx. 1943

SubAll. Alnenion glutinoso-incanae Oberd. 1953

Ass. Fraxino-Alnetum W.Mat. 1952

Ass. Piceo-Alnetum Sokol. 1980
Cl. Artemisietea vulgaris Lohm., Prsg et R.Tx. in

R.Tx. 1950

SubCl. Artemisienea vulgaris

O. Onopordetalia acanthii Br.-B1. et R.Tx. 1943 em. Görs 1966

All. Onopordion acanthii Br.-B1. 1926

Community Erigeron annuus-Senecio jacobea

Cl. Agropyretea intermedio-repentis (Oberd. et all. 1967) Müller et Görs 1969

O. Agropyretalia intermedio-repentis (Oberd. et all. 1967) Müller et Görs 1969

All. Convolvulo-Agropyrion repentisi Görs 1966

Ass. Convolvulo arvensis-Agropyretum repentis Felföldy 1943

In the studied area of the Czarna river valley eight species of vascular plants and mosses under strict and partial protection were identified [Dz.U. 2004, Nr 168, poz. 1764]. There were two species under strict protection (Daphne mezereum, Dactylorhiza maculta ssp. maculta) and six species under partial protection, including three species of vascular plants (Frangula alnus, Ribes nigrum, Viburnum opulus) and three moss species (Calliergonella cuspidata, Climacium dendroides, Eurhynchium angustirete (Figure 1).

\section{Numerical syntaxonomy of plant communities}

The results of numerical classification confirmed the field identification of syntaxons which are divided into two main groups of forest and non-forest communities, depending on the fertility of habitats, their moisture content, structure and species composition (Figure 2). The first group of forest communities $(1-$ releves 65-72) comprises two valuable forest communities (1a and 1b) mentioned in the Enclosure I to the Habitats Directive 92/43/EEC. These are two types of riparian forests: lowland Fraxino-Alnetum W.Mat. 1952 (code no. 91E0-3) and PiceoAlnetum Soko1. 1980 representing the north-east form (code no. 91E0-3). In the Czarna river valley, both these associations prefer hydrogenic soil and occupy humus sands and deposited alluvium of the valley bottoms. The group of nonforest communities (2) includes the non-forest communities, rush and sedge communities from the class Phramitetea and meadow communities from the class Molinio-Arrhenatheretea. They are divided into three subgroups (Figure 2). The sub- 


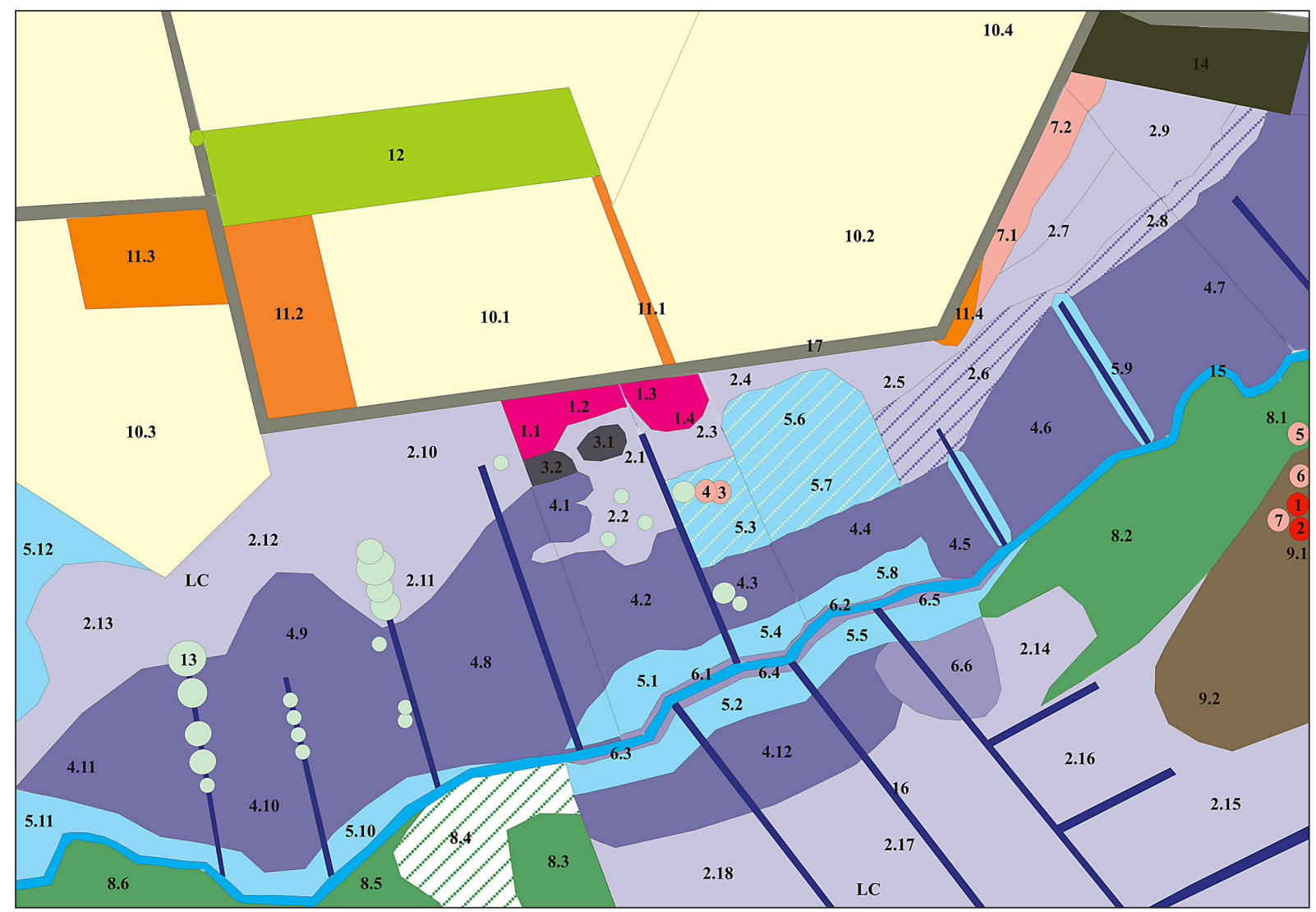

Legend:

Plant communities (1.2):

1 - unit of vegetation

2 - number of phytosocjological record

Non-forest and forest communities not protected by the Natura 2000

Ass. Angelico-Cirsietum oleracei R.Tx. 1937 em. Oberd. 1967

Ass. Lysimachio vulgaris-Filipenduletum ulmariae Bal.-Tul. 1978, including

ecotone between post-meadows herbs and sedge rushes

Ass. Scirpetum silvatici Ralski 1931

Ass. Caricetum acutiformis Sauer 1937

Ass. Phragmitetum australis (Gams 1927) Shmale 1939, including

spontaneous willow scrub communities

Ass. Caricetum appropinquatae (Koch 1926) Soó 1938

Community with Deschampsia caespitosa

Segetal agrocoenoses of cereal crops of the Cl. Stellarietea mediae R.Tx., Lohm. et Prsg, 1950

Agrocoenoses of wastelands, fallows, weeds associated with arable land of the Cl. Stellarietea mediae

Artificial forestation and greenwood with Betula pendula

Spontaneous willow scrub communities of the Cl. Alnetea glutinosae Br-Bl. et R.Tx. 1943

Ruderal communinities of the Cl, Artemisietea vulgaris Lohm., Prsg et R.Tx. In R.Tx. 1950

Aquatic plant communities of the Czarna river

Communities of aquatic plants artificial drainage ditches

Field roads, forest roads, roads

Forest communities protected by the Natura 2000

1.kod 91E0-3 - Ass. Fraxino-Alnetum W.Mat. 1952, including

2.kod 91E0-3 - Ass. Piceo-Alnetum Sokołowski 1980

Plant species under strict protection

(1) Daphne mezereum

Plant species under partial protectioní

3 Calliergonella cuspidata

Eurhynchium angustirete

Frangula alnus

Viburnum opulus

Figure 1. Floristic diversity of plant communities in the Czarna river valley 


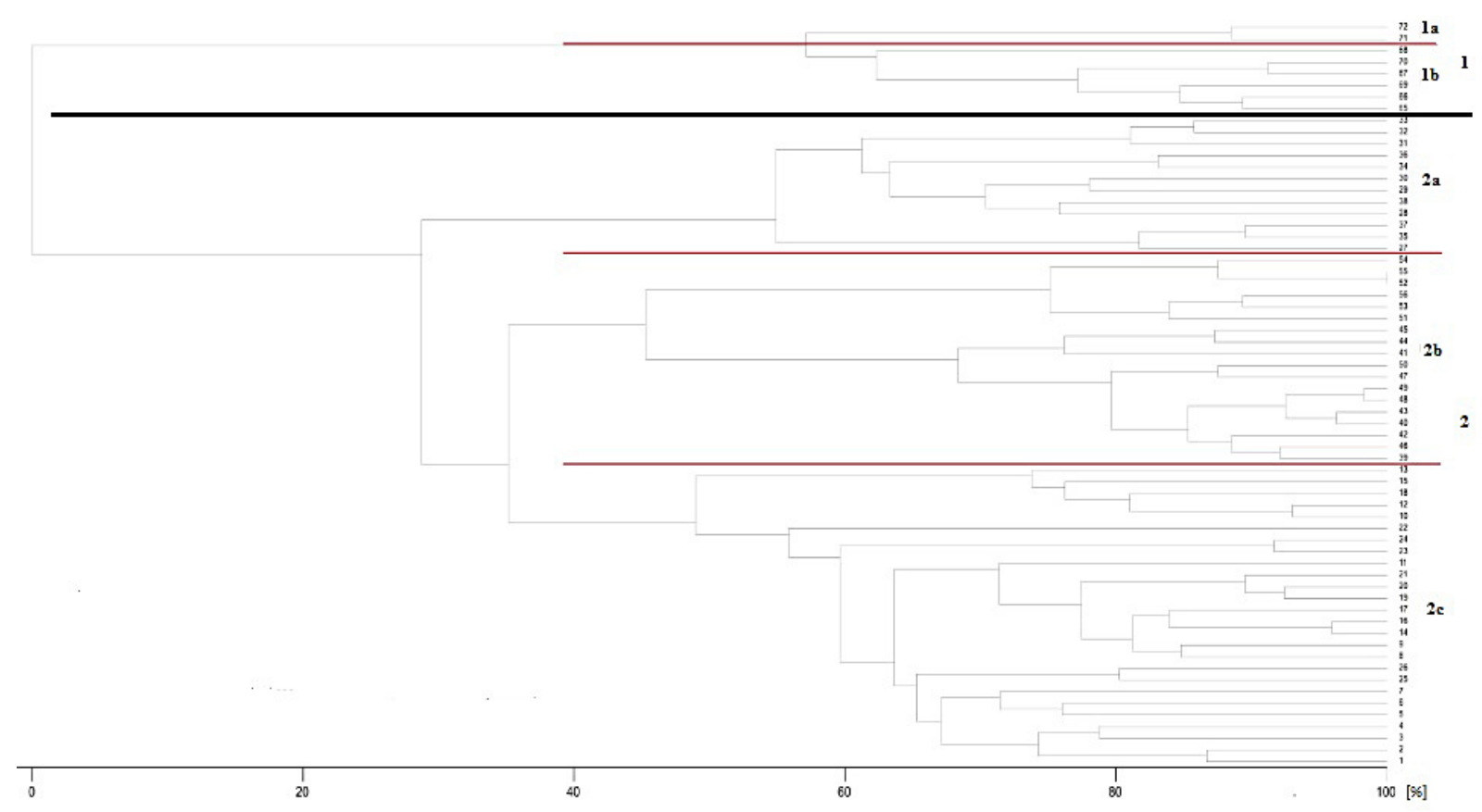

Figure 2. Hierarchical classification of plant communities of the Czarna river valley

The subgroup $2 \mathrm{c}$ represents all meadow communities from the class Molinio-Arrhenatheretea (releves 1-26), including Angelico-Cirsietum oleracei (releves 1-4), Lysimachio vulgaris-Filipenduletum ulmariae (releves 5-22) and meadows with Deschampsia caespitosa (releves 2324) and with Scirpus sylvaticus (releves 25-26) (Figure 2).

The principal components analysis, PCA, revealed the differentiation of the plant patches according to the moisture content of habitats, structure and species composition of the communities studied (Figure 3). The eigenvalues for the first and second axes of PCA reach $32.6 \%$ and $26.1 \%$, with the first axis explaining $25.8 \%$, while the second axis explaining $20.7 \%$ of the changes in the plant communities studied. In the upper part of the plot (cluster 2) on the first axis the highest values reach the rush communities (0.911) and sedge communities (0.711) from the class Phragmitetea. The environmental gradient represented by the first axis is interpreted as the gradient of moisture content of habitats, as the associations Phragimitetum australis, Caricetum acutiformis and Caricetum appropinquata (cluster 2) occur in the closest vicinity to the river bed. The cluster localised on the right hand side of the plot (cluster 1) reaches the highest values on the second axis (up to 0.886) and represents the meadow communities from the class Molinio-Arrhenatheretea, the cluster 3, on the left hand side of the plot reaches the values from -1.115 to -2.009 and represents forest communities Fraxino-Alnetum and PiceoAlnetum (Figure 3). The environmental gradient represented by the second axis points to a significant inner differentiation of the plant patches studied, dependent on the structures of associations and their floral composition.

\section{Evaluation of the present state of plant communities of the Czarna river valley}

According to the data collected, in the Czarna river valley forest communities occupy larger area (54\%) than non-forest communities (45.5\%) and thickets communities $(0.5 \%)$ (Table 1$)$. The forest communities comprised lowland riparian forest communities Fraxino-Alnetum and PiceoAlnetum (33.6\%), with increasing distance from the river bed changing to oak-hornbeam communities Tilio-Carpinetum (14.4\%), clear-cutting tree stands $(4.7 \%)$ and artificial infield forestation and young growth with Betula pendula (1.3\%).

Non-forest communities (45.5\%) developed mainly in the areas left after deforestation performed in the past in the valley, at present make stable grasslands intensely used as mown meadows Angelico-Cirsietum oleracei (0.3\%), land of agricultural use, arable land sown with oat, barley and rye (11.7\%) and idle land (1.3\%). Other nonforest communities met at present in the area of the Czarna river valley include abandoned meadows that have been transformed in the secondary succession into post-meadows herbs Lysimachio 


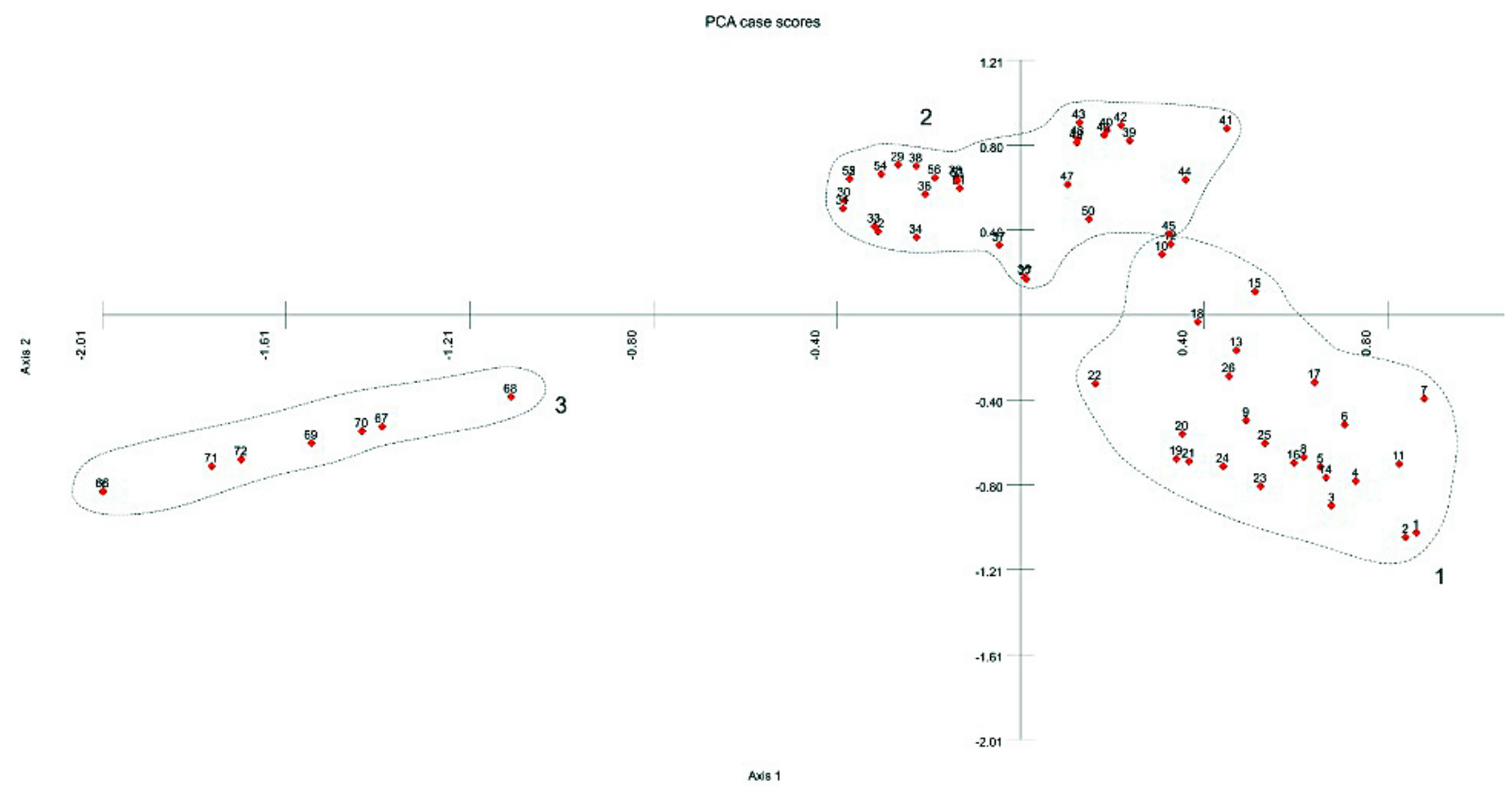

Figure 3. Principal Components Analysis (PCA) of plant communities of the Czarna river valley

vulgaris-Filipenduletum ulmariae (13\%) or have been grown with reeds making the communities of Phragmitetum australis (2.1\%) (Table 1). Other abandoned meadows are overgrown with Deschampsia caespitosa and Scirpus sylvaticus and represent the meadows with Deschampsia caespitosa $(0.3 \%)$ and Scirpetum silvatici $(0.1 \%)$. The other area in close vicinity to the Czarna river bed is occupied by sedges Caricetum acutiformis (6.1\%) and Caricetum appropinquatae (0.4\%). The strongest anthropogenically transformed areas are those occupied by human dwellings, they are occupied by synanthropic communities with ruderal vegetation $(3.6 \%)$.

\section{Valorisation of the plant communities in the Czarna river valley}

Valorisation of the nature has shown that the plant patches studied represent moderate (B classes IV-VI) or low (A - classes I and III) natural values (Table 2). Moderately high natural values (class VI) were assessed to the sedge rushes Caricetum appropinquatae, which occupies wet and periodically flooded habitats, in close vicinity of or directly at the river bed. Moderately average natural value (class $\mathrm{V}$ ) was assigned to rush communities Phragmitetum australis, occupying sites in direct neighbourhood of the river bed and drained and secondary silt-covered peat earth formations.

Four plant communities were assessed as reaching moderate natural values (class IV)
(Table 2); post-meadows herbs Lysimachio-Filipenduletum, wet meadows Scirpetum silvatici, wet meadows under extensive use AngelicoCirsietum oleracei and sedge rushes Caricetum acutiformis, occupying the wet and periodically flooded habitats as well as wet and periodically drying habitats. Small natural value (class III) was assigned to the wet meadow with Deschampsia caespitosa, and very small natural value (class I) was assigned to riparian forests Fraxino-Alnetum and Piceo-Alnetum, growing in wet habitats on previously deforested fragments of the Czarna river valley.

\section{DISCUSSION AND CONCLUSIONS}

The space-time analysis of the Czarna river valley landscape structure, conducted with the consideration for the changes in the mode of land use over the years 1966-2011, has shown that the area occupied by forest in wet habitats has increased as a result of secondary succession by $0.16 \mathrm{~km}^{2}$, which means by $27 \%$ with respect to the area of $0.4406 \mathrm{~km}^{2}$ taken by the forest in 1966 (Figure 4). The changes are a result of anthropogenic activity related to the changes in the mode of land use (abandonment of mowing) and in water conditions (drainage) [Dembek 2002]. The abandonment of land use leads to the development of post-meadow herbs followed by the appearance of willow thickets and riparian asso- 
Table 1. Area and percent contribution of the plant communities in the Czarna river valley in 2011

\begin{tabular}{|c|c|c|}
\hline Plant communities & Area [ha] & $\begin{array}{c}\text { Percent } \\
\text { contribution [\%] }\end{array}$ \\
\hline \multicolumn{3}{|l|}{ Non-forest communities } \\
\hline Ass. Angelico-Cirsietum oleracei & 0.16 & 0.27 \\
\hline Ass. Lysimachio vulgaris - Filipenduletum ulmariae & 7.74 & 12.88 \\
\hline Ass. Scirpetum silvatici & 0.07 & 0.11 \\
\hline Community with Deschampsia caespitosa & 0.15 & 0.25 \\
\hline Meadows (together) & 8.12 & 13.51 \\
\hline Ass. Phragmitetum australis & 2.07 & 3.45 \\
\hline Ass. Caricetum appropinquatae & 0.26 & 0.44 \\
\hline Ass. Caricetum acutiformis & 6.10 & 10.16 \\
\hline Rushes (together) & 8.43 & 14.05 \\
\hline Agrocenoses: segetal communities from the class of Stellarietea mediae & 7.04 & 11.72 \\
\hline Agrocenosis: wastelands, fallows, weed communities associated with class Stellarietea mediae & 0.77 & 1.28 \\
\hline Agrocenosis from the $\mathrm{Cl}$. Stellarietea mediae (together) & 7.81 & 13.00 \\
\hline Ruderal communities from the class of Artemisietea vulgaris & 0.33 & 0.56 \\
\hline Aquatic plant communities of the Czarna river & 0.38 & 0.64 \\
\hline Communities of aquatic plants artificial drainage diches & 0.43 & 0.72 \\
\hline Field roads, forest roads, roads & 1.79 & 2.99 \\
\hline Other non-forest (together) & 2.93 & 4.91 \\
\hline All the non-forest communities (together) & 27.29 & 45.5 \\
\hline \multicolumn{3}{|l|}{ Forest communities } \\
\hline Ass. Fraxino-Alnetum & 6.12 & 10.18 \\
\hline Ass. Piceo-Alnetum & 14.06 & 23.40 \\
\hline Ass. Tilio-Carpinetum & 8.67 & 14.42 \\
\hline Clear-cutting tree stands & 2.83 & 4.71 \\
\hline Forest communities (together) & 31.68 & 52.71 \\
\hline Other secondary forest - Artificial infield forestation and young growth with Betula pendula & 0.77 & 1.28 \\
\hline All the forest communities (together) & 32.45 & 54.0 \\
\hline Thickets communities Ass. Salicetum pentandro-cinereae & 0.32 & 0.54 \\
\hline Together all the communities & 60.06 & 100.0 \\
\hline
\end{tabular}

Table 2. The natural valorization of the plant communities in the Czarna river valley based on occurs of the plant species acc. to Oświt [2000]

\begin{tabular}{|l|c|c|c|c|c|c|c|c|c|}
\hline \multicolumn{1}{|c|}{ Plant communities } & 1 & 2 & 3 & 4 & 5 & 6 & 7 & 8 & 9 \\
\hline $\begin{array}{l}\text { Number of the plant } \\
\text { species in the record }\end{array}$ & 22 & 45 & 64 & 44 & 58 & 35 & 42 & 33 & 37 \\
\hline $\begin{array}{l}\text { Sum of natural } \\
\text { valorization points }\end{array}$ & 74 & 136 & 169 & 115 & 141 & 88 & 89 & 26 & 51 \\
\hline $\begin{array}{l}\text { Average number of the } \\
\text { natural valorization }\end{array}$ & 3.4 & 3.0 & 2.6 & 2.6 & 2.4 & 2.5 & 2.1 & 1.3 & 1.4 \\
\hline $\begin{array}{l}\text { The class of the natural } \\
\text { valorization }\end{array}$ & $\mathrm{VI}$ & $\mathrm{V}$ & $\mathrm{IV}$ & $\mathrm{IV}$ & $\mathrm{IV}$ & $\mathrm{IV}$ & $\mathrm{III}$ & $\mathrm{I}$ & $\mathrm{I}$ \\
\hline $\begin{array}{l}\text { The natural value: } \\
\text { A-small } \\
\text { B-moderate }\end{array}$ & $\begin{array}{c}\text { moderately- } \\
\text { high } \\
\text { B }\end{array}$ & $\begin{array}{c}\text { moderately- } \\
\text { average } \\
\text { B }\end{array}$ & moderate & moderate & moderate & moderate & small & $\begin{array}{c}\text { very } \\
\text { small } \\
\text { A }\end{array}$ & $\begin{array}{c}\text { very } \\
\text { small } \\
\text { A }\end{array}$ \\
\hline
\end{tabular}

Explanations: 1. Ass. Caricetum appropinquatae, 2. Ass. Phragmitetum australis, 3. Ass. Lysimachio vulgarisFilipenduletum, 4. Ass. Scirpetum silvatici, 5. Ass. Angelico-Cirsietum oleracei, 6. Caricetum acutiformis, 7. Community with Deschampsia caespitosa, 8. Ass. Fraxino-Alnetum, 9. Ass. Piceo-Alnetum 

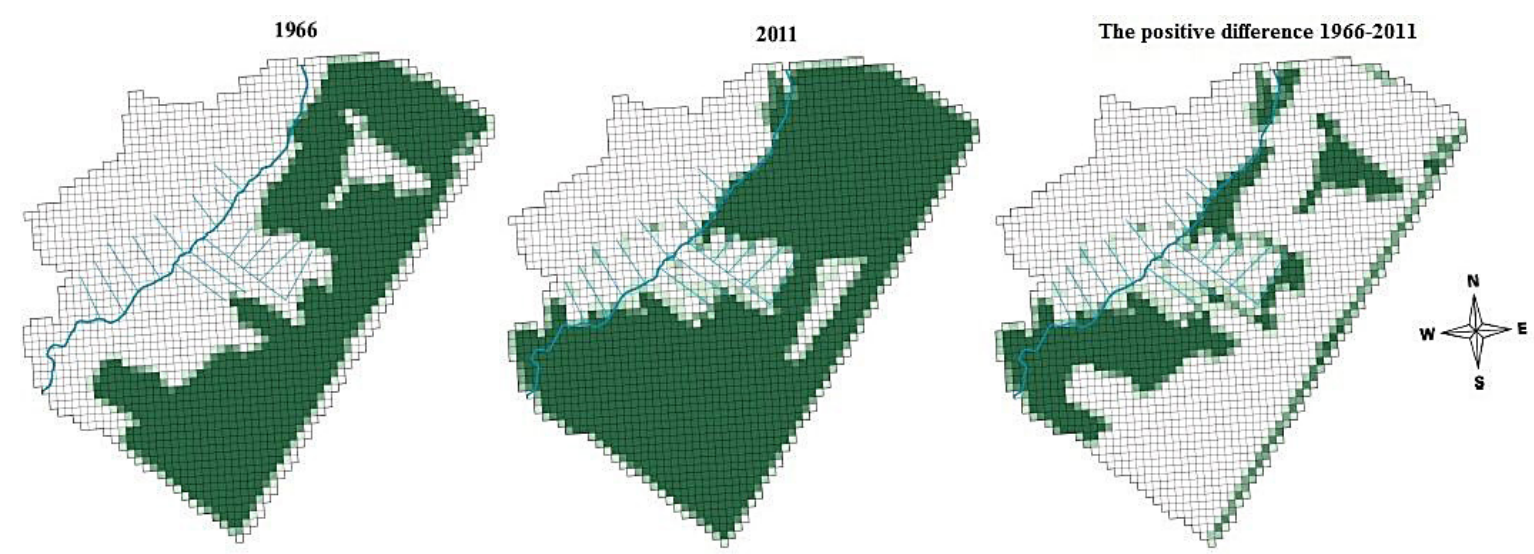

$0,0 \% \square \quad 1,0-20,0 \%$

$20,1-40,0 \%$

$40,1-60,0 \%$

$60,1-80,0 \%$
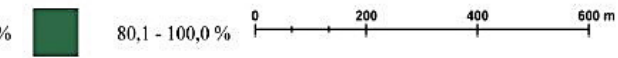

Figure 4. Change and positive growth forest area in the period 1966-2011 in the Czarna river valley [Łaska, Kolendo 2013, changed]

ciations [Kozłowska 2005, Kryszak et al. 2006]. Unmowed potential patches of Angelico-Cirsietum-olerace $i$ as a result of secondary succession are overgrown with post-meadow herbs Lysimachio vulgaris-Filipenduletum ulmariae (12.9\%) [Łaska 2008, 2009, 2012].

The area taken by the post-meadow communities increases also as a result of the conducive effect of the network of drainage ditches built on both sides of the Czarna river valley. As a result of overdrying of wetland habitats and initiation of processes of recreative secondary succession, the contributions of willow and alder shrubs and trees from the class of Alnetea glutinosae $(0.54 \%)$ increase at the expense of the area taken by grassland. It is a result of the abandonment of mowing and unfavourable hydrological conditions and leads to a gradual transformation of the spontaneous willows scrub communities into riparian communities in the process of secondary succession [Szewczyk 2004]. Chronological changes in the structure of vegetation in the area studied evaluated on the basis of GIS and digital methods indicate that in the wet meadows unmowed for many years, the recreative secondary succession leads to reproduction of the potential forest vegetation that grew in the Czarna river valley in the past.

\section{REFERENCES}

1. Dembek W., 2002. Problemy ochrony i restytucji mokradeł w Polsce. Inżynieria Ekologiczna, 6, 65-68.

2. Dembek W., Grzyb M., Mikułowski M., 2002. Łąki i lasy w dolinach - nowe zagrożenia i szanse.
Post. Nauk Rol. 3, 87-119.

3. Dz.U. 2004, Nr 168, poz. 1764. Rozporządzenie Ministra Środowiska z dnia 9 lipca 2004 roku w sprawie gatunków dziko występujących roślin objętych ochroną gatunkową.

4. Gamrat R., Burczyk P., 2007. Zbiorowiska roślinne doliny Warty na odcinku Santok-Stare Polichno. Woda Środ. Obsz. Wiej. 2(20), 127-136.

5. Gamrat R., Kochanowska R., Niedźwiedzki E., 2010. Zróżnicowanie warunków siedliskowych i zbiorowisk roślinnych $\mathrm{w}$ dolinie Iny $\mathrm{w}$ okolicach Sowna. Część III. Zróżnicowanie zbiorowisk łąkowych na tle warunków glebowych. Woda Środ. Obsz. Wiej. 1(29), 157-165.

6. Grzelak M., Janyszek M., Kaczmarek Z., Bocian T., 2008. Kształtowanie się różnorodności zbiorowisk szuwarowych z klasy Phragmitetea pod wpływem warunków siedliskowych. Woda Środ. Obsz. Wiej. 1(22), 99-108.

7. http://geoportal.gov.pl (access: 23.10.2011)

8. Kamiński J., 2008. Zróżnicowanie florystyczne i walory przyrodnicze łąk 2-kośnych na zagospodarowanym torfowisku w zależności od warunków wilgotnościowych. Woda Środ. Obsz. Wiej. 2(23), 87-104.

9. Kotowski W., 2002. Wartości przyrodnicze fitocenoz siedlisk rolniczych w dolinach rzecznych. [In:] Dembek W. (Ed.), Aktualne problemy ochrony mokradeł: walory przyrodnicze mokradeł a ich rolnicze użytkowanie. IMUZ, Falenty, 43-61.

10. Kozłowska T., 2002. Przeobrażenia siedlisk zbiorowisk łąkowych na obszarach źródliskowych. Woda Środ. Obsz. Wiej. 1(4), 77-87.

11. Kozłowska T., 2005. Zmiany zbiorowisk łąkowych na tle różnicowania się warunków siedliskowych w charakterystycznych obszarach dolin rzecznych Polski Centralnej. IMUZ, Falenty, 7-170. 
12. Kryszak J., Grynia M., 2005. Zbiorowiska trawiaste siedlisk nadmiernie uwilgotnionych $\mathrm{w}$ dolinach rzecznych. Łąkarstwo w Polsce 8, 97-106.

13. Kryszak A., Grynia M., Kryszak J., Będziński M., Grzelak M., 2004. Zmiany różnorodności florystycznej nadwarciańskich łąk zalewanych. Woda Środ. Obsz. Wiej. 1(10), 209-218.

14. Kryszak A., Kryszak J., 2007. Użytkowanie a walory przyrodnicze zbiorowisk łąkowych. Fr. Agron. 3, 258-267.

15. Kryszak A., Kryszak J., Grynia M., Czemko M., 2006. Dynamika zmian różnorodności florystycznej zbiorowisk trawiastych doliny Obry. Woda Środ. Obsz. Wiej. 1(16), 229-237.

16. Łaska G., 2008. Plant communities in wetland habitats in the Knyszyńska Forest - present state and anthropogenic transformations in the GIS approach. Polish Journal Enviromental Studies, 15, 207-214.

17. Łaska. G., 2009. Zbiorowiska roślinne siedlisk mokradłowych w Dolinie Płoski - ocena aktualnego stanu w zależności od różnych form użytkowania. Woda Środ. Obsz. Wiej. 4(28), 141-162.

18. Łaska G., 2011. "Natura 2000” ecological network in the aspect of sustainable development. Ecological Questions 15, 5-21.

19. Łaska G., 2012. Różnorodność i walory przyrodnicze zbiorowisk mokradłowych w dolinie Białej, w centrum Białegostoku. Inżynieria Ekologiczna 29, 87-98.

20. Łaska G., Kolendo M. 2013. Reconstruction of vegetation in the Czarna river valley with the use of numerical methods. [In:] Biedunkiewicz A., Dynowska M. (Eds.). Interdyscyplinarne i aplika- cyjne znaczenie nauk botanicznych. Streszczenia wystąpień ustnych i plakatów 56. Zjazdu PTB, Olsztyn, 356-357.

21. Matuszkiewicz W., 2001. Przewodnik do oznaczania zbiorowisk roślinnych Polski. PWN Warszawa.

22. Matysiak A., Dembek W., 2006. Różnorodność florystyczna zbiorowisk roślinnych na wybranych terenach porolnych Kampinowskiego Parku Narodowego. Woda Środ. Obsz. Wiej. 2(18), 231-254.

23. Mirek Z., Piękoś-Mirkowa H., Zając A., Zając M., 2002. Flowering Plants and Pteridophytes of Poland. A Checklist. Polish Academy of Sciences, Kraków.

24. Myśliwy M., 2010. Ocena warunków siedliskowych roślinności metodą fitoindykacyjną w wybranych jeziorach Puszczy Gorzowskiej. Woda Środ. Obsz. Wiej. 1(19), 109-121.

25. Ochyra R., Żarnowiec J., Bednarek-Ochyra H., 2003. Cenzus catalogue of Polish mosses. Polish Academy of Sciences, Kraków.

26. Oświt J., 2000. Metoda przyrodniczej waloryzacji mokradeł i wyniki jej zastosowania na wybranych obiektach. IMiUZ, Falenty, 3-35.

27. Piórkowski H., 2002. Kształtowanie szaty roślinnej, warunków siedliskowych i struktury przestrzennej krajobrazu doliny dolnej Pilicy pod wpływem antropopresji. [In:] Dembek W. (Ed.), Aktualne problemy ochrony mokradeł: walory przyrodnicze mokradeł a ich rolnicze użytkowanie. IMUZ, Falenty, 12-42.

28. Szewczyk M., 2004. Zbiorowiska roślinne nieleśne. [In:] Banaszuk H. (Ed.), Przyroda Podlasia. Narwiański Park Narodowy. Wydawnictwo Ekonomia i Środowisko, Białystok. 